\title{
Antibacterial Activity of Common Spices Extracts on Bacterial Isolates Found in Kachhila, a Newari Cuisine
}

\author{
Shiv Nandan Sah ${ }^{1}$, Hemanta Khanal ${ }^{1}$, Dev Raj Acharya ${ }^{2}$ \\ ${ }^{1}$ Department of Microbiology, Central Campus of Technology, Dharan, Tribhuvan University, Nepal \\ ${ }^{2}$ Central Department of Food Technology, Central Campus of Technology,Dharan Tribhuvan University, Nepal \\ Corresponding author: Shiv Nandan Sah, Department of Microbiology, Central Campus of Technology, \\ Tribhuvan University, Dharan. E-mail: sahshivnandan96@gmail.com
}

\begin{abstract}
Objectives: The objective of this study was to determine the antibacterial property of aqueous extracts of common spices used in the preparation of Kachhila such as garlic, ginger, and turmeric.

Methods: After washing and cleaning separately, aqueous extracts were extracted from each spice by crushed with mortar and pestle. Antibacterial activity of aqueous extracts of each spice was evaluated by using agar well diffusion assay and paper disc diffusion assay against test bacteria isolated from buff meat used in Kachhila preparation.

Results: Minimum inhibition concentration value of each spice was evaluated against all bacterial isolates. Total bacterial count (CFU/g) of prepared Kachhila was determined in each 30 mins interval up to 150 mins to reveal antibacterial activities of spices used in Kachhila. The antibacterial effect of aqueous extract of garlic extract was found to be the stronger in comparison, followed by turmeric and ginger against test bacterial isolates. The MIC of individual spice extract was found to be 125 to $4000 \mu \mathrm{l} / \mathrm{ml}$ against all the test bacteria. Spices used in Kachhila revealed that bacterial load decreased with time due to the antibacterial property of spices.
\end{abstract}

Conclusion: This study concluded that the antibacterial effect of aqueous extract of Garlic extract was stronger in comparison, followed by Turmeric and Ginger against four test bacteria isolated from buff meat namely; E. coli, Salmonella spp., Pseudomonas spp., Staphylococcus aureus. Therefore this study revealed that spices used in Kachhila have an antibacterial property and enhance the shelf life of Kachhila.

Keywords: Antibacterial property, Spices, Minimum Inhibitory Concentration, Kachhila

\section{INTRODUCTION}

Kachhila, one of the most popular snack items belonging to the Newari community, is made of raw meat. One among the two of the most popular cuisines, Choila and Kachhila, it is a cuisine especially unique to the Newari community. The Newari community is considered one of the richest communities in terms of culinary experience (Personal communication). The term meat refers to the flesh, skeletal muscle, and any attached connective tissue or fat excluding bone and bone marrow (Williams 2007). Meat is a good source of protein, essential fatty acids, minerals and vitamins but easily perishable because it

Date of Submission: August 18, 2020

Published Online: December, 2020 provides a suitable medium for the growth of various microorganisms (Komba et al. 2012). Buffalo meat is the healthiest meat among red meats, known for human consumption because it is low in calories and cholesterol (Ranjhan 2013). It has almost 2-3 folds cost advantage over mutton and goat meat (APEDA 2008). The most important food-borne bacteria transmitted through meat include Salmonella, Shigella, Staphylococcus aureus, Escherichia coli, Campylobacter jejuni, Listeria monocytogenes, Clostridium perfringens, Yersinia enterocolitica, and Aeromonas hydrophila (Zhao et al. 2001; Bhandare et al. 2007).

Date of Acceptance: October 22, 2020

DOI: https:/ / doi.org/10.3126/tujm.v7i0.33785 
Spices have been used for many centuries by various cultures to enhance the flavor and aroma of our foods as our ancestors have recognized the usage of spices in food preservation and in the treatment of clinical ailments and there are several reports on the development of antibiotic resistance in diverse bacterial pathogens (Oli 2011). Spices are indispensable components of Nepalese cuisines since ancient times (Mahanrjan et al. 2019). The activity of herbs and spices is not only used to boosting flavor but also recognized for their preservative and medicinal value (Panpatil et al. 2013). The burgeoning concern about the safety of foods has recently led to the development of natural antimicrobials to control foodborne pathogens (Maharjan et al. 2019). The addition of spices in food imparts not only flavor and aroma of the foods but also provides antimicrobial properties (Nanasombat et al. 2002), due to the presence of their naturally derived components (Maharjan et al. 2019). Spices are parts of a plant that are used for providing the aroma, flavor, or piquancy to food and also for seasoning the food (Oli 2011). Spices have been defined as plant substances from the indigenous or exotic origin, aromatic or with strong taste, used to enhance the taste of foods (Germano and Germano 1998). Basically, spices are used for flavouring, masking the bad flavor of some foods, appetizer preservation, colouring of food, ayurvedic medicines, and even in cosmetics and perfumes. The composition of spices includes proteins, lipids, carbohydrates, vitamins, and various mineral compounds. The other constituents, however, are essential oil and oleoresins which give characteristic taste and flavor (Parry 1969).

Spices may contribute piquancy of foods and beverages (Praveen et al. 2006). Spices have been widely used in rituals and as flavorings and coloring agents since ancient times (Gottardi et al. 2016); but, various recent studies have increasingly reported on the antibacterial activity of spices against common Grampositive and Gram-negative bacteria responsible for human infectious diseases and food safety problems (Irshad et al. 2017). Spices containing antimicrobial compounds are some of the most commonly used natural antimicrobial agents in foods (Indu et al. 2006). Therefore, actions must be taken to control this problem by using the plant extracts containing phytochemical having antimicrobial properties. (Agaoglu et al. 2007). Spices have been recognized for their value of preserving foods and medicinal values due to the presence of bioactive antimicrobial compounds (Papp et al. 2007). Being plants, the natural foodstuffs, spices appeal to consumers who tend to question the safety of synthetic additives (Sagdiç et al. 2003). The spices have a unique aroma and flavor which are derived from compounds known as phytochemicals or secondary metabolites (Avato et al. 2000). The phytochemicals are antimicrobial substances present in the spices which are capable of attracting benefits and repel harmful organisms; they also serve as photoprotectants and responds to environmental changes. Numerous classes of phytochemicals including the isoflavones, anthocyanins, and flavonoids are found associated with the spices (Feldberg et al. 1989).

The meat is a nutrient-dense medium ideal for many pathogens and spoilage microbes to colonize because of its high in moisture, rich in nitrogenous foods of various complexity, plentifully supplied with minerals and accessory growth factor, usually has some fermentable carbohydrate (glycogen), and is at favorable pH (Frazier and Westhoff 2009). The bacterial pathogens most frequently identified from illness associated with beef products are Salmonella spp., Campylobacter, Staphylococcus aureus, Escherichia coli, Listeria monocytogenes, Clostridium perfringens, Yersinia enterocolitica, Bacillus cereus, and Vibrio parahaemolyticus (Gandhi and Chikinda 2007). Hence the main aim of this study is to isolate the bacteria found in the meat sample used for Kachhila and to evaluate the antimicrobial property of the extract from respective spices against the isolated bacteria.

\section{MATERIALS AND METHODS \\ Collection of spices}

The ginger roots, fresh garlic, and turmeric were collected in plastic bags from the Dharan market in March 2019 and this study was carried out up to May 2019 months in the microbiology laboratory of Central Campus of Technology, Hattisar, Dharan.

For the study of antimicrobial activity of spices extracts, their different concentrations were tested on different test bacteria (Staphylococcus aureus, E. coli, Salmonella spp. and Pseudomonas spp.) isolated from buff meat ready for the preparation of Kachhila.

\section{Isolation of bacteria from buff meat}

About $5 \mathrm{~g}$ of buffalo meat sample was collected in a clean, dry, and sterile polythene bag from the local market of Dharan and transported to the laboratory and 
immediately processed for isolation of bacteria within one hour or refrigerated at $4^{\circ} \mathrm{C}$ till further analysis were carried out and processed no later than 10 hours after purchase.

1 gram of the sample was first crushed and ground in a sterile mortar with the help of a sterile pestle and the $9 \mathrm{ml}$ of sterile distilled water was added and further proceeded to serial dilution. Isolation of test bacteria was carried out from the various dilutions by using various selective medium and differential media by spread plate technique (Jarallah et al. 2014).

After gram staining, biochemical tests were performed for the identification of the genera and species of the organisms. The identification of significant isolates was done by using standard microbiological techniques as described in Bergey's Manual (Holt et al. 1994). After identification, the antibiotic susceptibility test of the isolates was done by the modified Kirby-Baur disc diffusion method as recommended by the Clinical Laboratory Standards Institute using Muellen-Hilton Agar (MHA) (CLSI 2006).

\section{Preparation of spices extract}

The collected spices were cleaned, descaled when necessary, and washed in sterile distilled water. In order to obtain the spice's extracts, about $100 \mathrm{~g}$ of each washed spice was crushed with mortar and pestle. The extracts were sieved through a fine mesh cloth and sterilized using a membrane filter (0.45-micron sterile filter). This extract was considered as the $100 \%$ concentration of the extract. The concentrations $75 \%$, $50 \%$ and $25 \%$ were made diluting the concentrated extract with appropriate volumes of sterile distilled water (Joe et al. 2009).

Garlic extract was made differently due to the difficulty to filter the crushed material. One hundred grams of the descaled and cleaned garlic was taken and surface sterilized using ethanol. The ethanol was allowed to evaporate in a sterile laminar flow chamber, and the garlic was homogenized aseptically using a sterile mortar and pestle. The extract was aseptically squeezed out using sterile cheesecloth as done by Indu et al. (2006).

The aqueous extract $(8 \mathrm{ml}$ of $1000 \mu \mathrm{l} / \mathrm{ml}$ or $100 \%)$ was concentrated to $1 \mathrm{ml}$ to make $8000 \mu \mathrm{l} / \mathrm{ml}$ as a stock solution by using heat at $40^{\circ} \mathrm{C}$ in a water bath. Then it was diluted by half fold dilutions $(4000 \mu \mathrm{l} / \mathrm{ml}, 2000 \mu \mathrm{l} /$ $\mathrm{ml}, 1000 \mu \mathrm{l} / \mathrm{ml}, 500 \mu \mathrm{l} / \mathrm{ml}, 250 \mu \mathrm{l} / \mathrm{ml}, 125 \mu \mathrm{l} / \mathrm{ml}, 62.5$ $\mu \mathrm{l} / \mathrm{ml}$ ) for determination of MIC value of each spice extract against test bacteria.

Antibacterial activity testing using agar well method The isolated bacteria from meat going to be prepared as Kachhila by using their selective media were inoculated into $10 \mathrm{ml}$ of sterile nutrient broth and incubated at $37^{\circ}$ C for 16-18 hours (0.5 Mc Far-land Standards).

Using a sterile cotton swab, the nutrient broth culture was swabbed on the surface of sterile Mueller-Hinton Agar (MHA) plates. Agar wells were prepared with the help of a sterilized cork borer with a $6 \mathrm{~mm}$ diameter. Using a micropipette, 100 microlitres of different concentrations of spices extracts $(100 \%, 75 \%, 50 \%$, and $25 \%)$ were added to different wells on the plate. The plates were incubated in an upright position at $37^{\circ} \mathrm{C}$ for 24 hours.

The diameter of inhibition zones was measured in $\mathrm{mm}$ and the $\mathrm{r}$ were recorded. The inhibition zones with a diameter of less than $6 \mathrm{~mm}$ were considered as having no antibacterial activity.

Antibacterial activity testing using the filter paper disc method

For comparison with agar cup methods of antimicrobial assay, the filter paper disc method was also applied. Filter paper discs of $6 \mathrm{~mm}$ diameter were prepared and sterilized (Paper disc thickness taken was 0.05 $\mathrm{mm})$. Using ethanol dipped and flamed forceps, these discs were aseptically placed over Mueller-Hinton Agar (MHA) plates seeded with the respective test microorganisms (Srinivasan et al. 2001). Ten microlitres of the various spices' extract from stock (10 times concentrated) was aseptically transferred to these discs. The plates were incubated in an upright position at $37^{\circ}$ $C$ for 24 hours. The diameter of inhibition zones were measured in $\mathrm{mm}$ and the results will be recorded.

- The concentration taken for filter paper disc assay was 10 times so that the amount of spice extract poured in agar cup was equivalent to the amount in paper disc.

\section{Antibiotic susceptibility testing}

The test microorganisms was also tested by modified Kirby Bauer Disc Diffusion methods for their sensitivity against the antibiotics (Hi-media, India) such as chloramphenicol (30 mcg), ciprofloxacin (5 $\mathrm{mcg})$, nalidixic acid (30 mcg), streptomycin (10 mcg) and tetracycline $(30 \mathrm{mcg}$ ) by the disc diffusion method.

The cultures were subcultured in sterile nutrient broth for 6-8 hours) at $37^{\circ} \mathrm{C}$ and turbidity was matched with 
that of 0.5 Mac Farland standard . Using sterile cotton swabs, the cultures were aseptically swabbed on the surface of sterile Mueller-Hinton Agar (MHA) plates. Using an ethanol dipped and flamed forceps, the antibiotic discs were aseptically placed over the seeded MHA plates sufficiently separated from each other to avoid overlapping of the inhibition zones. The plates were incubated at $37^{\circ} \mathrm{C}$ for 24 hours and the diameter of the inhibition zones were measured in $\mathrm{mm}$. All the media used in the present investigation was obtained from Hi-media Laboratories Ltd., Mumbai, India.

\section{Preparation of control plate}

One control plate was prepared in each experiment by agar well diffusion to sterilized distilled water instead of ginger, garlic, and turmeric extract. Control plate was essential and very important to measure and determine whether the spice extract was the substance that will kill the bacteria and not cause by other elements and factors. The inhibitory effect of these spices was compared with that of 5 control antibiotics (chloramphenicol, ciprofloxacin, nalidixic acid, streptomycin and tetracycline).

Evaluation of bacterial load after preparation of Kachhila

Buff Meat was minced into suitable small pieces that were used to prepare Kachhila according to a standard protocol. Bacterial load before and after use of spices in preparation of Kachhila were evaluated by performing serial dilution of $1 \mathrm{~g}$ sample followed by spread plate technique on Plate count agar. After preparation of Kachhila without adding salt, bacterial load was determined at various intervals of time viz. 0 mins, 30 mins, 60 mins, 90 mins, 120 mins and 150 mins respectively.

\section{RESULTS}

A total of 3 different spices (Garlic, Ginger and Turmeric) were included in this study, collected from local market of Dharan. The crude extracts of spices were tested against altogether four test bacteria isolated from buffalo meat usually used for preparation of Kachhila.

Antibacterial activity testing using agar well method Overall, it was observed that among three spices, aqueous extracts of Garlic had inhibitory effect on both gram-positive and gram-negative bacteria.The different concentrations $(100 \%, 75 \%, 50 \%$ and $25 \%)$ of aqueous extract of garlic showed least inhibition values $(15 \mathrm{~mm}$, $12 \mathrm{~mm}, 11 \mathrm{~mm}$ and $6 \mathrm{~mm}$ ) against $E$. coli and highest inhibition values $(21 \mathrm{~mm}, 20 \mathrm{~mm}, 17 \mathrm{~mm}$ and $11 \mathrm{~mm}$ ) against $S$. aureus. Similarly, the different concentrations $(100 \%, 75 \%, 50 \%$ and $25 \%)$ of aqueous extract of garlic showed zone of inhibition values such as $18 \mathrm{~mm}, 17$ $\mathrm{mm}, 16 \mathrm{~mm}$ and $11 \mathrm{~mm}$ against Salmonella spp. and 19 $\mathrm{mm}, 18 \mathrm{~mm}, 16 \mathrm{~mm}$ and $7 \mathrm{~mm}$ against Pseudomonas spp. respectively (Table 1).

Table 1: Antibacterial activity of spices extract in

different percentage against test bacteria (the agar cup assay method)

\begin{tabular}{|c|c|c|c|c|c|c|c|c|c|c|c|c|}
\hline \multirow{3}{*}{ Bacteria } & \multicolumn{12}{|c|}{ Diameter of inhibition zone (in $\mathrm{mm}$ ) against various concentrations of spices extract (\%) } \\
\hline & \multicolumn{4}{|c|}{ Garlic } & \multicolumn{4}{|c|}{ Turmeric } & \multicolumn{4}{|c|}{ Ginger } \\
\hline & 100 & 75 & 50 & 25 & 100 & 75 & 50 & 25 & 100 & 75 & 50 & 25 \\
\hline E. coli & 15 & 12 & 11 & 6 & - & - & - & - & - & - & - & - \\
\hline Salmonella spp. & 18 & 17 & 16 & 11 & - & - & - & - & - & - & - & - \\
\hline Pseudomonas spp. & 19 & 18 & 16 & 7 & - & - & - & - & - & - & - & - \\
\hline S. aureus & 21 & 20 & 17 & 11 & - & - & - & - & - & - & - & - \\
\hline
\end{tabular}

Antibacterial sensitivity testing using the filter paper disc diffusion method

Discs containing 100\% garlic extracts showed $9 \mathrm{~mm}$ against E. coli, $13 \mathrm{~mm}$ against Salmonella spp., $12 \mathrm{~mm}$ against Pseudomonas spp., and $15 \mathrm{~mm}$ against $S$. aureus
(Table 2). Based on zone of inhibition, Antibacterial activity of Garlic was found to be less effective by paper disc diffusion method than agar well method. 


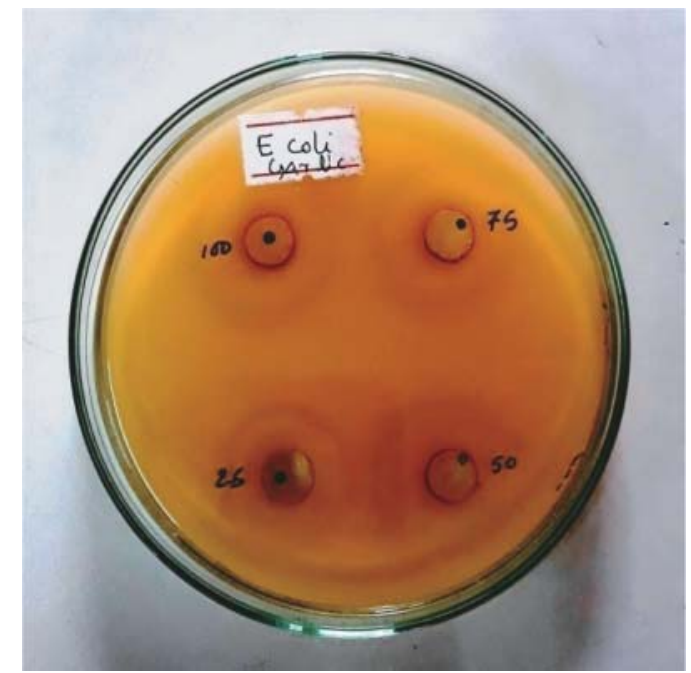

Photograph 1: Zone of inhibition of garlic against Escherichia coli

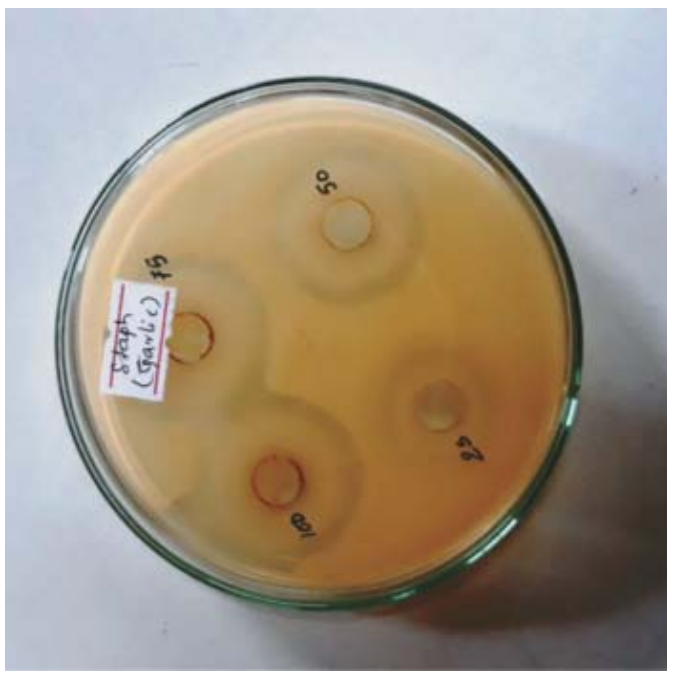

Photograph 3: Zone of inhibition of garlic against Staphylococcus aureus

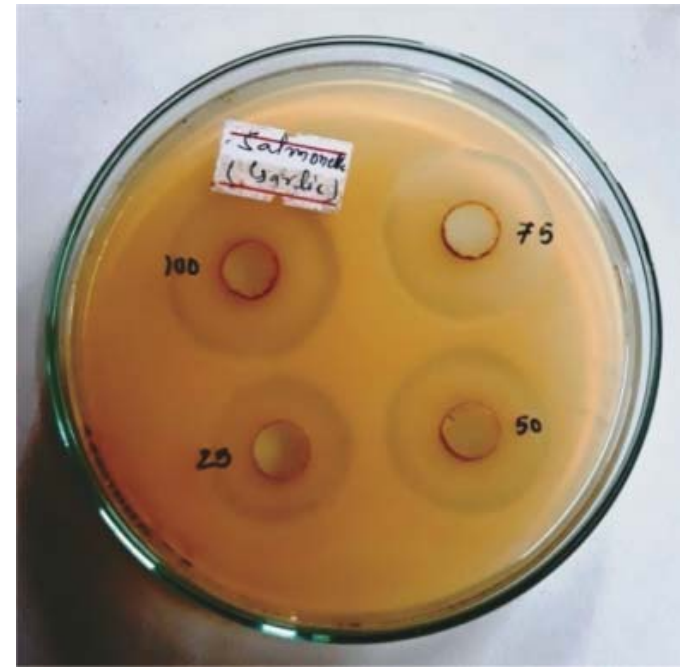

Photograph 2: Zone of inhibition of garlic against Salmonella spp.

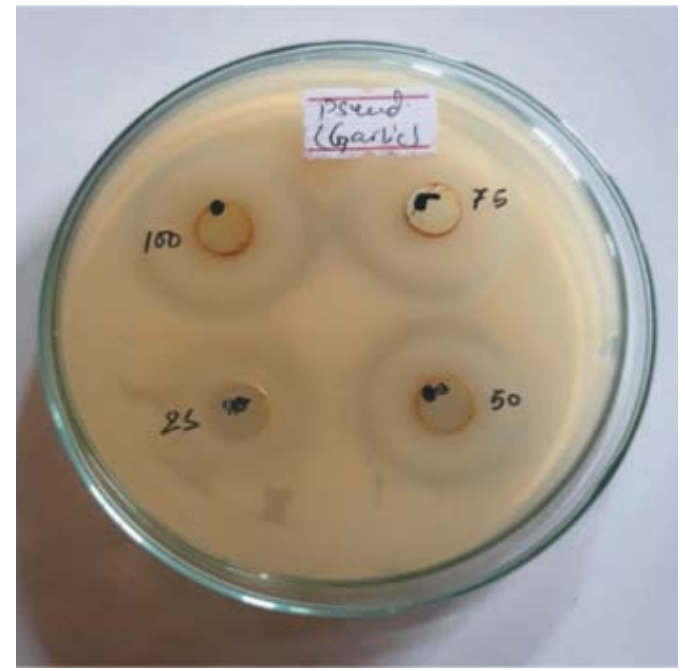

Photograph 4: Zone of inhibition of garlic against Pseudomonas spp.

Table 2: Antibacterial activity of spices extract in different percentage against test bacteria (the filter paper disc diffusion method)

\begin{tabular}{cccc}
\hline & \multicolumn{2}{c}{ Zone of inhibition (in mm) of spices extract (100\%) against test bacteria } \\
\cline { 2 - 4 } Bacteria & Garlic & Turmeric & Ginger \\
& 100 & 100 & - \\
E. coli & 9 & - & - \\
Salmonella spp. & 13 & - & - \\
Pseudomonas spp. & 12 & - & - \\
S. aureus & 15 & & \\
\hline
\end{tabular}

\section{Antibiotic susceptibility testing}

All isolates except Staphylococcus aureus were resistant to chloramphenicol. E. coli and Staphylococcus aureus were found to be intermediate while Salmonella spp. and Pseudomonas spp. were found to be resistant to ciprofloxacin.

Salmonella spp. and Staphylococcus aureus were susceptible whereas Pseudomonas spp. was resistant but E. coli was intermediate to nalidixic acid. Pseudomonas 
spp. was intermediate to streptomycin while remaining was susceptible to streptomycin. Both Salmonella spp. and $S$. aureus were found to be susceptible to tetracycline while Pseudomonas spp. was resistant but E. coli was found to be Intermediate (Table 3).

Table 3: Antibiotic susceptibility pattern of isolated test bacteria from buff meat

\begin{tabular}{lccccc}
\hline \multirow{2}{*}{ Organism } & \multicolumn{5}{c}{ Zone of inhibition against antibiotic (mm) } \\
\cline { 2 - 6 } & Chloramphenicol & Ciprofloxacin & Nalidixic acid & Streptomycin & Tetracycline \\
& $(\mathbf{3 0}$ & $(\mathbf{1 5 )}$ & $\mathbf{( 3 0 )}$ & $\mathbf{( 1 0 )}$ & $\mathbf{( 3 0 )}$ \\
\hline E. coli & $-(\mathrm{R})$ & $20(\mathrm{I})$ & $21(\mathrm{I})$ & $23(\mathrm{~S})$ & $8(\mathrm{I})$ \\
Salmonella spp & $-(\mathrm{R})$ & $16(\mathrm{R})$ & $23(\mathrm{~S})$ & $16(\mathrm{~S})$ & $15(\mathrm{~S})$ \\
Pseudomonas spp & $22(\mathrm{R})$ & $22(\mathrm{R})$ & $(\mathrm{R})$ & $20(\mathrm{I})$ & $16(\mathrm{R})$ \\
S. aureus & $24(\mathrm{~S})$ & $22(\mathrm{I})$ & $19(\mathrm{~S})$ & $22(\mathrm{~S})$ & $24(\mathrm{~S})$ \\
\hline
\end{tabular}

Determination of MIC of spices extract against test bacteria

MICs of three spices extracts were determined for all four test bacterial isolates (E. coli, Salmonella spp., Pseudomonas spp., and Staphylococcus aureus).

For garlic extract, MIC values were $125 \mu \mathrm{l} / \mathrm{ml}$ against
Salmonella spp. and Staphylococccus spp., and $250 \mu \mathrm{l} /$ $\mathrm{ml}$ against E. coli and Pseudomonas spp. For turmeric extract, E. coli and Staphylococcus aureus have similar MIC value (i.e. $1000 \mu \mathrm{l} / \mathrm{ml}$ ) as well as Salmonella spp. and Pseudomonas spp. have also similar MIC (i.e. 2000 $\mu \mathrm{l} / \mathrm{ml})$. In case of Ginger extract, MIC was found to be $4000 \mu \mathrm{l} / \mathrm{ml}$ against all four bacteria (Table 4).

Table 4: Minimum inhibitory concentration $(\mu \mathrm{l} / \mathrm{ml})$ of spices extract against test bacteria.

\begin{tabular}{lcccc}
\hline \multicolumn{1}{c}{ Spices extract } & E. coli & Salmonella spp. & Pseudomonas spp. & Staphylococcus aureus \\
\hline Garlic & 250 & 125 & 250 & 125 \\
Turmeric & 1000 & 2000 & 2000 & 1000 \\
Ginger & 4000 & 4000 & 4000 & 4000 \\
\hline
\end{tabular}

\section{Evaluation of bacterial load in Kachhila}

The bacterial load of fresh buff meat was found to be $26 \times 10^{4} \mathrm{CFU} / \mathrm{g}$. Again the bacterial load was determined from prepared Kachhila without adding salt and found to be $53 \times 10^{4} \mathrm{CFU} / \mathrm{g}, 85 \times 10^{4} \mathrm{CFU} / \mathrm{g}, 76 \times 10^{4} \mathrm{CFU} / \mathrm{g}$,
$64 \times 10^{4} \mathrm{CFU} / \mathrm{g}, 51 \times 10^{4} \mathrm{CFU} / \mathrm{g}$ and $44 \times 10^{4} \mathrm{CFU} / \mathrm{g}$ at 0 mins, 30 mins, 60 mins, 90 mins, 120 mins and 150 mins respectively. This showed bacterial load in Kacchila was decreased with time due antibacterial activities of spices used (Table 5).

Table 5: Bacterial load per gram meat before and after use of spices in preparation of Kachhila

\begin{tabular}{lcc}
\hline \multicolumn{1}{c}{ Sample (1 g) } & Time (mins) & Bacterial load (CFU/g) \\
\hline Meat & Market meat before addition of spices without salt & $26 \times 104$ \\
Kachhila & 0 mins & $53 \times 104$ \\
Kachhila & $30 \mathrm{~min}$ & $81 \times 104$ \\
Kachhila & $60 \mathrm{mins}$ & $76 \times 104$ \\
Kachhila & $90 \mathrm{mins}$ & $64 \times 104$ \\
Kachhila & $120 \mathrm{mins}$ & $51 \times 104$ \\
Kachhila & $150 \mathrm{mins}$ & $44 \times 104$ \\
\hline
\end{tabular}




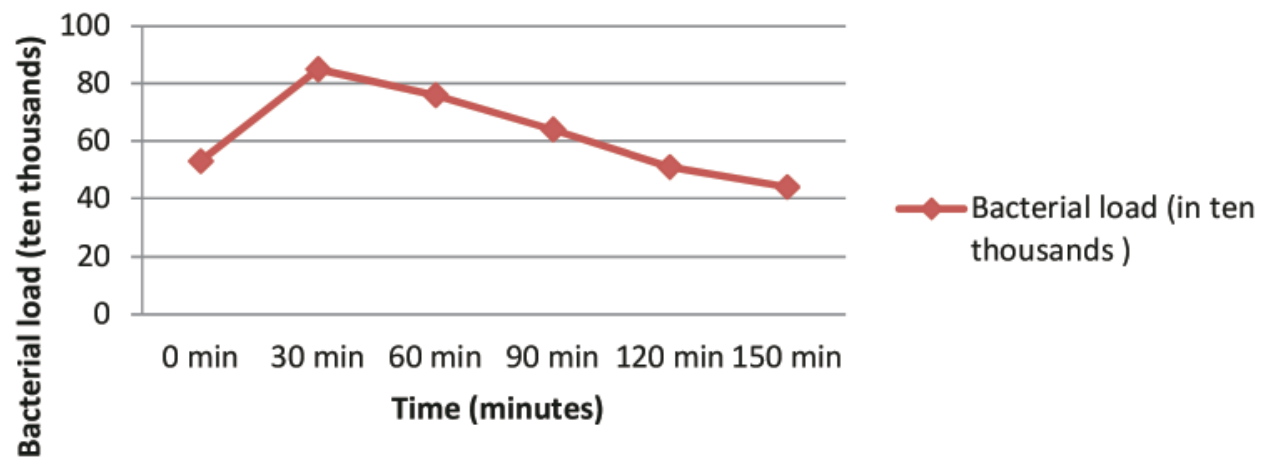

Figure 1: Time (mins) wise activity of spices on bacterial load (CFU/g) in Kachhila

\section{DISCUSSION}

Buffalo meat has gained importance in the recent years because of its domestic needs and export potential. Buffalo meat is well comparable to beef in many of the physicochemical, nutritional, functional properties and palatability attributes (Anjaneyulu et al. 1990). Furthermore, its utility in meat processing is on increase because of higher content of lean meat and less fat. The microbiological condition of fresh raw meat of local market of Dharan can be assumed to be heavily contaminated with spoilage and pathogenic organisms (Bantawa et al. 2018). The increased resistance of isolates against commonly used antibiotics may be due to the indiscriminate use of common antibiotics. The variation on the rate of resistance can be related to the difference in time and place. Another reason for the difference in resistance rates might be a rapid change in antibiotic sensitivity patterns of bacteria within a short period (Bantawa et al. 2019). The prevalence of antibiotic-resistant bacteria is increasing due to the haphazard use of antibiotics in human therapy, animal farming and other prophylactic usages (Addis et al. 2011).

Resistance enables bacteria to escape from being killed by antibiotics and reduces the ability to treat infections (Spellberg et al. 2008). Therefore, antibiotics resistance has been considered one of the greatest threats to medicine (Walker et al. 2009). Meat also plays an important role in the transfer of antibiotics resistant genes in term of antibiotic residues.

Foodborne pathogens are the leading causes of illness and death in less developed countries (Blaser 1997).
Therefore, nowadays, the awareness has been growing on the public health impact of zoonotic foodborne pathogens transmitted from animal originated food in especially developing countries (Zhao et al. 2001). The growing concern about food safety has recently led to the development of natural antimicrobials to control food borne pathogens and spoilage bacteria. Spices are one of the most commonly used natural antibacterial agents in foods and have been used traditionally for thousands of years by many cultures for preserving foods and as food additives to enhance aroma and flavour (Punir and Jain 2010). Many of the spices and herbs used today have been valued for their antibacterial effects and medicinal powers in addition to their flavor and fragrance qualities (Bin et al. 2007)

A wide range of technologies is available for the extraction of active components and essential oils from medicinal and aromatic plants. The choice depends on the economic feasibility and suitability of the process to the particular situation. Many of the plant materials used in traditional medicine are readily available in rural areas at relatively cheaper than modern medicine (Duhan et al. 2013).

This study was performed to evaluate the antibacterial activity of aqueous extracts of some common spices against common gram positive and gram negative bacteria found in buff meat used in preparation of Kachhila. This study showed aqueous extracts of garlic had a strong effect against all bacteria, while that of turmeric had a weak effect. However, the Ginger extracts could show no zone of inhibition against any test bacteria. 
Different serogroups responded differently to the garlic extract at different concentrations. At 100\% concentration E. coli serogroup $\mathrm{O} 1$ was least sensitive (18 $\mathrm{mm})$ and serogroup O22 and O25 were more sensitive $(30 \mathrm{~mm})$. Both enterohemorrhagic $E$. coli (EHEC, serogroup O157) and enterotoxigenic E. coli (ETEC, serogroup O8) were highly sensitive to garlic extract (Indu et al. 2006).

The results showed that the bacterial load in prepared Kachhila decreased with time, however, in first 30 mins, the bacterial load was found to be increased and then decreased. It was basically due to antibacterial property of spices used in Kachhila which is itself a good source of nutrients for bacterial growth and at the same time, spices could not show antibacterial property due to deficient antibacterial extract from spices. These findings proved antibacterial property of spices which increased shelf life of Kachhila by decreasing bacterial load that might cause meat spoilage in sufficient numbers along with time. From these results, Bacterial growth in Kachhila was found to be resultant of growth promoting factors (Meat nutrients, moisture temperature etc) and growth retarding factors (spices extract). As spices have antibacterial property, they can be used for other various food items for better taste and preservation. According to Venugopal et al. (2018), addition of herbs and spices to the food preparations helps to keep a check on the concentration Escherichia coli in the body.

The inhibitory effect of these spices was compared with that of 5 antibiotics (chloramphenicol, ciprofloxacin, nalidixic acid, streptomycin and tetracycline) and the results are discussed.

According to Indu et al. (2005), the antibacterial activity of the spices was less evident in paper disc method than that of the agar cup assay method; however garlic extract $(100 \%)$ maintained good antibacterial activity against all the test organisms.

The mechanism of antibacterial action of spices and derivatives is not yet clear. Proposed hypothesis are : hydrophobic and hydrogen bonding of phenolic compounds to membrane proteins, followed by partition in the lipid bilayer; perturbation of membrane permeability consequent to its expansion and increased fluidity causing the inhibition of membrane embedded enzymes; membrane disruption; destruction of electrons transport systems and cell wall perturbation
(Punir and Jain 2010). In various previous studies, the antibacterial properties of spices are mostly attributed to lipophilic essential oils (Nikolic et al. 2014). However, hydrophilic antioxidants are also common in spices (Masuda et al. 2015), such as polyphenols, many of which possess excellent antioxidant as well as good antibacterial activity (Coccimiglio et al. 2016).

It is considered that microbial contamination and lipid oxidation are the two major factors resulting in food spoilage (MozaffariNejad et al. 2014). Hydrophilic extract of spice has good antibacterial and antioxidant activities; hence, can be used as natural food preservatives. For instance, extracts of cinnamon, oregano, and especially clove, were confirmed to be effective for retarding lipid oxidation and reducing pathogen numbers in real food matrices like cheese and raw pork (Shan et al. 2011; Shan et al. 2009). Besides, spice extracts could be applied in foods not only to increase shelf-life but also enhance health benefits of foods because probiotic bacteria like lactic acid bacteria (LAB) were less affected by the presence of these phenolic rich spice extracts (Chan et al. 2018).

The results demonstrated that the E. coli was more resistant to the spices extract than $S$. aureus. Gramnegative bacteria have an outer membrane rich in lipopolysaccharides (LPS) having high hydrophobicity, as well as a unique periplasmic space. The complex composition and spatial structure of lipopolysaccharides form a barrier for penetration of mostly for hydrophobic molecules and antimicrobial agents. Similarly, the presence of enzymes in periplasmic space may break down intrusive molecules, preventing the antibacterial drugs entering intracellular environment. Hydrophobic molecules can pass through cell wall of gram-positive bacteria easier than the gram-negative bacteria because cell wall of the gram-positive bacteria contained only peptidoglycan (Ababutain 2011; Shan et al. 2007).The antibacterial activity seemed to be bacteria-dependent, and Gram-positive bacteria were more susceptible to the tested spice extracts than Gram-negative bacteria(Benmeziane etal. 2018;Nagy et al. 2015)

Active compound in Garlic is Allicin (Rahman et al. 2006) which has antibacterial properties. Active compound in Ginger is phenyl propanoid derived compounds particularly gingerols and shogaols. Some volatile compounds which are responsible for antimicrobial activities in ginger were á-pinene, 
borneol, camphene, and linalool (Sa-Nguanpuag et al. 2011). Similarly the active compound in Turmeric (Curcuma longa) is Curcumin (Majeed et al. 1996).

Based on this finding, Spices possess good natural antimicrobial agents against both gram-positive and gram-negative bacteria. The extracts of spices should be further analyzed to isolate the specific antibacterial component in them.Various experiments should be conducted to prove spices as food preservatives. Clinical trials should be carried out to explore the potential of the extracts in the treatment of the infectious diseases.

More studies should be carried out for synergistic inhibitory effects as more effective antimicrobial agents. Also, the knowledge on efficacy of combined extracts may be extended from culinary food applications to pharmacology and food chemistry.

\section{CONCLUSION}

It is concluded that the antibacterial effect of aqueous extract of Garlic extract was stronger followed by Turmeric and Ginger against four test bacteria isolated from buff meat namely; E. coli, Salmonella spp., Pseudomonas spp., Staphylococcus aureus. Therefore this study revealed that spices used in Kachhila have antibacterial property and enhance the shelf life of Kachhila. Spices can be used as alternative natural food preservatives rather than chemicals. Various spices have different types of active ingredients that suppress the growth of bacteria present in food.

\section{ACKNOLEDGEMENTS}

We would like to express our sincere gratitude to Research Committee for providing Faculty Research Grant for this study and Department of Microbiology, Central Campus of Technology (Tribhuvan University) for providing laboratory facilities that are required for smooth and efficient passage of work required for the completion of the project.

\section{CONFLICT OF INTEREST}

The authors declare that they have no conflict of interest.

\section{REFERENCES}

Ababutain IM (2011) Antimicrobial activity of ethanolic extracts from some medicinal plant. Australian Journal of Basic and Applied Sciences 5: 678-683.

Addis Z, Kebede N, Sisay Z, Alemayehu H, Yirsaw A and Kassa T (2011) Prevalence and antimicrobial resistance of Salmonella isolated from lactating cows and in contact humans in dairy farms of Addis Ababa: a cross-sectional study. BMC Infectious Diseases 11:222.

Agaoglu S, Dostbil N and Alemdar S (2007) Antimicrobial activity of some spices used in the meat industry. Bulletin of the Veterinary Institute in Pulawy 55:53-57.

Anjaneyulu ASR Lakshmanan V, Sharma N and Kondaiah N (1990). Buffalo meat production and meat quality: A review. Indian Food Packer 44(4): 21-31.

APEDA (2008) Export of agro and processed food products including meat and meat products. Agricultural and Processed Food Products Export Development Authority: Ministry of Commerce \&Industry, Government of India, New Delhi.

Avato P, Tursil E, Vitali C, Miccolis V and Candido V (2000) Allylsulfide constituents of garlic volatile oil as antimicrobial. Phytomedicine 7 (3): 239-243.

Bantawa K, Rai K, Limbu DS and Khanal H (2018) Foodborne bacterial pathogens in marketed raw meat of Dharan, eastern Nepal. BMC Research Notes 11:618.

Bantawa K, Sah SN, Limbu DS and Subba P and Ghimire A (2019) Antibiotic resistance patterns of Staphylococcus aureus, Escherichia coli, Salmonella, Shigella and Vibrio isolated from chicken, pork, buffalo and goat meat in eastern Nepal. BMC Research Notes 12:766.

Benmeziane F, Djermoune-Arkoub L, Hassan KA and Zeghad H (2018) Evaluation of antibacterial activity of aqueous extract and essential oil from garlic against some pathogenic bacteria. International Food Research Journal 25 (2):561-564.

Bhandare SG, Sherikar AT, Paturkar AM, Waskar VS and Zende RJ (2007) A comparison of microbial contamination on sheep/goat carcasses in a modern Indian abattoir and traditional meat shops. Food Control 18 (7):854-868.

Bin S, Cai Yi-Z, Brooks JD, Corke H (2007) The in vitro antibacterial activity of dietary spice and medicinal herb extracts. International Journal of Food Microbiology 117(1): 112-119

Blaser MJ (1997) Epidemiologic and clinical features of Campylobacter jejuni infections. Journal of Infectious Diseases 176 (Suppl. 2):S103-105.

Chan CL, Gan RY, Shah NP and Corke H (2018) Polyphenols from selected dietary spices and medicinal herbs differentially affect common 
food-borne pathogenic bacteria and lactic acid bacteria. Food Control 92:437-443.

Clinical and Laboratory Standards Institute/ NCCLS (2006) Performance standards for antimicrobial susceptibility testing; 15th informational supplement. CLSI/NCCLS M100-S15: Clinical and Laboratory Standards Institute, Wayne PA.

Coccimiglio J, Alipour M, Jiang ZH, Gottardo C and Suntres Z (2016) Antioxidant, antibacterial, and cytotoxic activities of the ethanolic Origanum vulgare extract and its major constituents. Oxid Med Cell Longev. 1404505.

Duhan JS, Kumar A and Tanwar SK (2013) Bioethanol production from starchy part of tuberous plant (potato) using Saccharomyces cerevisiae MTCC-170. African journal of Microbiology Research 7(46):52535260.

Feldberg RS, Chang SC, Kotik AN, Nadler M, Neuwirth Z, Sundstrom DC and Thompson NH (1989) In vitro mechanism of inhibition of bacterial cell growth by allicin. Antimicrobial Agents and Chemotherapy 32(12): 1763-1768.

Frazier WC and Westhoff DC (2009) Food Microbiology. New Delhi, India: Tata McGraw-Hill Publishing Company Limited.

Gandhi M and Chikindas ML (2007) Listeria: a foodborne pathogen that knows how to survive. International Journal of Food Microbiology 113 (1):1-15.

Germano PML and Germano MIS (1998) Importânciaeriscos das especiarias. Higiene Alimentar 12: 239-312.

Gottardi D, Bukvicki D, Prasad S and Tyagi AK (2016) Beneficial effects of spices in food preservation and safety. Frontiers in Microbiology 7:1394.

Holt JG, Krieg NR, Sneath PHA, Staley JT, and Williams ST (1994) Bergey's Manual of Determinative Bacteriology (9 $9^{\text {th }}$ edition). Baltimore: Williams \& Wilkins

Indu MM, Hatha AAM, Abirosh C, Harsha U and Vivekanandan G (2006) Antimicrobial activity of some of the south-indian spices against serotypes of Escherichia coli, Salmonella, Listeria monocytogenes and Aeromonas hydrophila, Brazilian Journal of Microbiology 37:153-158.

Irshad S, Ashfaq A, Muazzam A and Yasmeen A (2017) Antimicrobial and anti-prostate cancer activity of turmeric (Curcuma longa L.) and black pepper (Piper nigrum L.) used in typical Pakistani cuisine.
Pakistan Journal of Zoology 49:1665-1669.

Jarallah EM, Sahib SI and Yassen K (2014). Isolation and identification of some pathogenic bacterial species contaminated from meats in butchers shops and Kebab restaurants in AL-Kut city. Euphrates Journal of Agriculture Science 6 (4): 30-37

Joe MM, Jayachitra J and Vijayapriya M (2009) Antimicrobial activity of some common spices against certain human pathogens. Journal of Medicinal Plants Research 3 (11):1134-1136.

Komba EV, Komba EV, Mkupasi EM, Mbyuzi AO, Mshamu S, Mzula A and Luwumba D (2012) Sanitary practices and occurrence of zoonotic conditions in cattle at slaughter in Morogoro Municipality, Tanzania: implications for public health. Tanzania Journal of Health Research 14:1-12.

Maharjan R, Thapa S and Acharya A (2019) Evaluation of antimicrobial activity and synergistic effect of spices against few selected pathogens. Tribhuvan University Journal of Microbiology 6 (1): 10-18

Majeed M, Badmaev V, Shivakumar U and Rajendran R (1995). Curcuminoids. Antioxidant Phytonutrients.. Piscataway, NJ, USA: Nutriscience Publishers, Inc

Masuda H, Hironaka S, Matsui Y, Hirooka S, Hirai M, Hirata Y, Akao M, Kumagai H (2015). Comparative study of the antioxidative activity of culinary herbs and spices, and hepatoprotective effects of three selected Lamiaceae plants on carbon tetrachlorideinduced oxidative stress in rats. Food Science and Technology Research 21:407-418.

MozaffariNejad AS, Shabani S, Bayat M, Hosseini SE (2014) Antibacterial effect of garlic aqueous extract on Staphylococcus aureus in hamburger. Jundishapur Journal of Microbiology 7(11): e13134.

Nagy M, SocaciSA, Tofan M, Pop C, Mure san C, Pop Cuceu AV, Salan L and Rotar AM (2015) Determination of total phenolics, antioxidant capacity and antimicrobial activity of selected aromatic spices. Bulletin of University of Agricultural Sciences and Veterinary Medicine Cluj-Napoca. Food Science and Technology 72(1): 82-85.

Nanasombat S, Prasertsin V, Graisin K, Shain H and Thanaboripat B (2002) Efficacy of new Enzymelinked Immunosorbent Assay for rapid detection of Salmonella in Foods. Government Pharmaceutical Organization Report, Bangkok 51: 53-57.

Nikolic M, Glamoclija J, Ferreira ICFR, Calhelha RC, Fernandes A, Markovic T, Markovic D, Giweli 
A and Sokovic M (2013) Chemical composition, antimicrobial, antioxidant and antitumor activity of Thymus serpyllum L., Thymus algeriensis Boiss. and Reut and Thymus vulgaris L. essential oils. Industrial Crops and Products 52:183-190.

Oli P (2011) Post-Harvest Technology of Tea, Coffee and Spices: Lalitpur Valley College, Nepal.

Panpatil VV, Tattari S, Kota N, Nimgulkar C and Polasa K (2013). In vitro evaluation of antioxidant and antimicrobial activity of spice extracts of ginger, turmeric and garlic. Journal of Pharmacognosy and Phytochemistry 2 (3):143-148

Papp LV, Holmgren J, Lu A and Khanna KK (2007) From Selenium to selenoproteins: synthesis, identity, and their role in human health. Pakistan Journal Botany 9 (7): 775-806.

Parry JW (1969) Spices. Volume I and II. New York: Chemical Publishing Company, Inc.

Perween T and Nazia MAC (2006) Bactericidal activity of black pepper, aniseed and coriander against oral isolates. Pakistan Journal of Pharmaceutical Sciences 19 (3): 214-218.

Pundir RK, Jain P (2010) Comparative studies on the antimicrobial activity of black pepper (Piper Nigrum) and turmeric (Curcuma Longa) extracts. International Journal of Applied Biology and Pharmaceutical Technology 1 (2): 492-501.

Rahman MS, Al-Sheibani HI, Al-Riziqi MH, Mothershaw A, Guizani N and Bengtsson G (2006) Assessment of the anti-microbial activity of dried garlic powders produced by different methods of drying. International Journal of Food Prop. 9: 503-513.

Ranjhan S (2013) Latest concepts in rearing buffaloes for meat production. Buffalo Bulletin 32: 319-328.

Sagdiç O, Karahan A, Ozcan Mand Ozkan G (2003) Effect of some spice extracts on bacterial inhibition, Food Science and Technology International 9 (5): 353-358.

Sa-Nguanpuag K, Kanlayanarat S, Srilaong V, Tanprasert K and Techavuthiporn C (2011) Ginger (Zingiber officinale) oil as an antimicrobial agent for minimally processed produce: a case study in shredded green papaya. International
Journal of Agric. Biol.13:895-901.

Shan B, Cai YZ, Brooks JD and Corke H (2007) The in vitro antibacterial activity of dietary spice and medicinal herb extracts. International Journal of Food Microbiology 117:112-119.

Shan B, Cai YZ, Brooks JD and Corke H (2009) Antibacterial and antioxidant effects of five spice and herb extracts as natural preservatives of raw pork. Journal of the Science Food and Agriculture 89:1870-1885.

Shan B, Cai YZ, Brooks JD and CorkeH (2011) Potential application of spices and herb extracts as natural preservatives in cheese. Journal of Medicinal Food 14: 284-290.

Spellberg B, Guidos R and Gilbert D (2008) The epidemic of antibiotic-resistant infections: a call to action for the medical community from the infectious diseases society of America. Clinical Infectious Diseases 46(2):155-164.

Srinivasan et al. (2001) Antimicrobial activity of certain Indian medicinal plants used in folkloric medicine. Journal of Ethnopharmacology 74 (3):217-220.

Venugopal T, Ali MM, Bourassa MA, Zheng Y,Goni GJ, Foltz GR and Rajeevan M (2018) Statistical evidence for the role of southwestern Indian ocean heat content in the Indian summer monsoon rainfall. Scientific Reports 8: 12092.

Walker B, Barrett S, Polasky S, Galaz V, Folke C, Engström G, Ackerman F, Arrow K, Carpenter S, Chopra K, Daily G, Ehrlich P, Hughes T, Kautsky N, Levin S, Mäler KG, Shogren J, Vincent J, Xepapadeas T and deZeeuw A (2009) Environment looming global-scale failures and missing institutions Science 325 (5946):1345-1346.

Williams P (2007) Nutritional composition of red meat. Nutrition \& Dietetics 64(Suppl.4):S113-S119.

Zhao C, Ge B, Villena J, Robert S, Emily Y, Shaohua Z, David G, David W and Jianghong M (2001) Prevalence of Campylobacter spp., Escherichia coli and Salmonella serovars in retail chicken, turkey, pork and beef from the greater Washington D.C. area. Applied and Environmental Microbiology 67(12):5431-5436. 